\title{
Security\& Privacy Threats, AtTacks And COUNTERMEASURES IN INTERNET OF THINGS
}

\author{
Faheem Masoodi ${ }^{1}$ Shadab Alam ${ }^{2}$ and Shams Tabrez Siddiqui ${ }^{2}$ \\ ${ }^{1}$ Department of Computer Science, University of Kashmir, J\&k, India \\ ${ }^{2}$ Department of Computer Science, Jazan University, KSA
}

\begin{abstract}
The idea to connect everything to anything and at any point of time is what vaguely defines the concept of the Internet of Things (IoT). The IoT is not only about providing connectivity but also facilitating interaction among these connected things. Though the term IoT was introduced in 1999 but has drawn significant attention during the past few years, the pace at which new devices are being integrated into the system will profoundly impact the world in a good way but also poses some severe queries about security and privacy. IoT in its current form is susceptible to a multitudinous set of attacks. One of the most significant concerns of IoT is to provide security assurance for the data exchange because data is vulnerable to some attacks by the attackers at each layer of IoT. The IoT has a layered structure where each layer provides a service. The security needs vary from layer to layer as each layer serves a different purpose. This paper aims to analyze the various security and privacy threats related to IoT. Some attacks have been discussed along with some existing and proposed countermeasures.
\end{abstract}

\section{KEYWORDS}

Internet of Things, privacy, attacks, security, threats, protocols.

\section{INTRODUCTION}

Kevin Ashton in 1999 coined the term 'Internet-of-Things (IoT)' [1] and was primarily used to describe how IoT can be created by "adding radiofrequency identification and other sensors to everyday objects." Today the term IoT encompasses a set of heterogeneous devices that are connected via some communication protocols and sensors, which enable us to locate, identify and operate upon these devices.

The 'things' in IoT are the entities that are involved in communication among themselves and with the environment in which they exist and are responsible for generating large amounts of data and information. For making physical or virtual connections, it uses objects like sensors, actuators, etc. The success of IoT infrastructure and applications depends on IoT security. The IoT collects the data from a vast geographical region using sensors [1].

The Cisco Internet Business Solutions Group (IBSG) has come up with a ballpark figure of 50 billion IoT devices by 2020 , and the rationale for this massive number is the numerous and attractive services provided by IoT. Communication protocols that played a vital role in the emergence of IoT include Wireless Sensor Networks (WSN), Radio-Frequency Identification (RFID), Internet protocols and mobile communications. The concept of IoT devices is not onlyabout providing connectivity but also interaction among themselves. The need of the hour is that they should deploy context-based interactions [2]. There will be billions of devices interacting among each other over the internet, that will surely open doors for hackers, and with 
International Journal of Network Security \& Its Applications (IJNSA) Vol. 11, No.2, March 2019

that, there will be a lot many security threats that will need immediate supervisions. In the IoT infrastructure, the sensors and objects are integrated for communications that can work successfully without human interventions. The sensors play an essential role in the IoT as these are devices that not only collect heterogeneous data but also monitor it [3][4].

The goal of IoT is to provide a network infrastructure for interactions between sensor devices and other humans and objects. The IoT has a layered structure where each layer provides a service. The security needs vary from layer to layer as each layer serves a different purpose [5]. A considerable number of issues need to be addressed with regard to the IoT infrastructure. The reasons being the following:

$>$ Nature of smart objects

$>$ Usage of standard protocols

$>$ The bidirectional flow of information

The security issues like privacy, authorization, verification, access control, system configuration, information storage, and management are the real challenges of the IoT infrastructure [6]. Undoubtedly, to make IoT a reality, the security issues need to be resolved. IoT is the future generation internet.

The two types of challenges that we need to focus on are technological and security challenges.

The technical difficulties include wireless technologies and the distributed nature of the IoT while as the problems related to authentication and confidentiality are involved in the security[7].The major IoT principles include confidentiality, authentication, availability, heterogeneity, lightweight solutions, key management, policies, and integrity

\section{IOT ARCHITECTURE}

IoT has a three-layered architecture. The three layers are as:

- The Application Layer

- The Network Layer

- The Perception Layer

The Application Layer: The main aim of the application layer is to provide services to its users[8].

The Network Layer: The layer that is most prone to attacks is the network layer as it aggregates data from existing infrastructures and it transmits that data to other layers. The primary security issues are related to the authentication and integrity of data that is being transmitted [9].

The Perception Layer: The lowest layer of the IoT architecture and also the brain of the threelayered architecture. It is the physical layer.The sensing devices like the sensors are present on this layer. It is also known as sensors layer [10].

\begin{tabular}{|c|c|}
\hline IOT Layers & Protocols \\
\hline Application layer & CoAP, DDS, MQTT, SMQTT, AMQP \\
\hline Network layer & 6Lowpan, RPL, CORPL, CARP, 6TISCH \\
\hline & LTE-A, Z-Wave, Zigbee smart, DASH7, \\
Perception Layer & $802.11 \mathrm{ah}$ \\
\hline
\end{tabular}

Table 1. Different protocols that are present on different layers 
International Journal of Network Security \& Its Applications (IJNSA) Vol. 11, No.2, March 2019

\begin{tabular}{|c|c|}
\hline PROTOCOLS & PURPOSE \\
\hline CoAP & $\begin{array}{l}\text { CoAP is designed in such a way that it enables the low-power sensors to } \\
\text { make usage of restful services It is built upon the UDP instead of the } \\
\text { TCP that is commonly used in HTTP. }\end{array}$ \\
\hline DDS & $\begin{array}{l}\text { It provides an excellent quality of service levels and reliability that suits } \\
\text { the IoT and M2M communication. }\end{array}$ \\
\hline MQTT & $\begin{array}{l}\text { It facilities the embedded connectivity between applications and the } \\
\text { middleware's at one side and networks and communications on the other }\end{array}$ \\
\hline SMQTT & In this one message is encrypted but delivered to multiple other nodes. \\
\hline AMQP & $\begin{array}{l}\text { In this, the broker is divided into two main components that are exchange } \\
\text { and queues. }\end{array}$ \\
\hline 6LoWPAN & $\begin{array}{l}\text { 6LoWPAN is designed to work with variant length addresses, various } \\
\text { network topologies including mesh and star, low bandwidth, scalable } \\
\text { networks, mobility, and low cost }\end{array}$ \\
\hline RPL & $\begin{array}{l}\text { Routing Protocol for Low-Power and Lossy Networks (RPL) supports } \\
\text { data link protocol. }\end{array}$ \\
\hline CORPL & $\begin{array}{l}\text { An extension of RPL is CORPL or cognitive RPL, which is designed for } \\
\text { the cognitive networks and uses DODAG topology generation. }\end{array}$ \\
\hline CARP & $\begin{array}{l}\text { A distributed routing protocol is designed for the underwater } \\
\text { Communication. It has lightweight packets. }\end{array}$ \\
\hline $6 \mathrm{TiSCH}$ & $\begin{array}{l}\text { A 6TiSCH working group in IETF is developing standards to allow IPv6 } \\
\text { to pass through Time- Slotted Channel Hopping (TSCH) mode of IEEE } \\
802.15 .4 \text { e data links. }\end{array}$ \\
\hline LTE-A & $\begin{array}{l}\text { LTE-A is a scalable, lower- cost protocol as compared to other cellular } \\
\text { protocols. }\end{array}$ \\
\hline Z-WAVE & $\begin{array}{l}\text { Z-Wave is a low-power MAC protocol that is designed for home } \\
\text { automation. }\end{array}$ \\
\hline \multirow[t]{2}{*}{ Zigbee Smart Energy } & $\begin{array}{l}\text { It is designed for a broad range of IoT applications including Smart } \\
\text { homes, remote controls, and healthcare systems. It supports a wide star, } \\
\text { peer-to-peer or cluster-tree topologies. }\end{array}$ \\
\hline & $\begin{array}{l}\text { The objective is to support scalable networks with more extended } \\
\text { distance coverage at higher data rates. }\end{array}$ \\
\hline IEEE $802.11 \mathrm{AH}$ & $\begin{array}{l}\text { IEEE } 802.11 \mathrm{ah} \text { is a low energy version of the original IEEE } 802.11 \\
\text { wireless medium access standard. }\end{array}$ \\
\hline
\end{tabular}

Table 2. Application, network and perception layer protocols [11-23].

\section{SECURITY REQUIREMENTS}

The security and privacy issues have emerged as one of the primary concern in IoT implementation. Fig. 1 shows the web search of these terms measured by Google search trends since Jan 2004. It is clear that since 2014, search volume is increasing for both the terms primarily because of the large scale integration of IoT devices during last five years and increasing concern among the users about the confidentiality and privacy of their information contained in the systemWhile as Privacy includes the concealment of personal information as well as the ability to control what happens with this information [27][29], IoT security is concerned with safeguarding "things" in the Internet of things. IoT systems are prone to security attacks for a variety of reasons including the wireless communication between devices, physical access to objects, the constrained capacity of smart devices and openness of the system [30]. Broken devices or permanent failures of such devices provide vulnerabilities and can,therefore be exploited by potential attackers. A typical example of such devices can be RFID tags. 


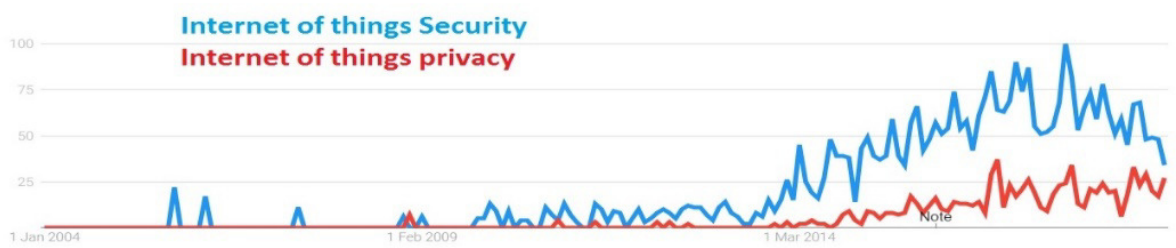

Fig. 1. Google search trends since 2004 for terms IOT Security, IOT Privacy

What makes privacy an essential IoT requirement lies in the anticipated IoT application domains and the technologies used. IoT adoption is harnessed due to lack of adequate measures for ensuring the privacy of information in variant IoT application fields like patient's remote monitoring, energy consumption control, traffic control, smart parking system, inventory management, and production chain,etc. [31]. Additionally, the adoption of wireless communication medium for data exchange can lead to a potential risk of privacy violation as exchanges over such medium can expose the underlying system to multiple attacks. Under these circumstances, security and privacy represent a real research challenge that may restrict IoT development. In an attempt to address these security and privacy concerns, we need to provide strict measures to protect data and tackle privacy risks. The underlying security properties that need to be implemented are confidentiality, authenticity, integrity and availability. Some other security requirements are derivedsuch as scale, IP Protocol-Based IoT, Heterogeneous IoTand Lightweight Security.

\section{IOT SECURITY Threats AND ATtaCKS}

The Internet of things offers many applications that are of substantial value to the user but at the same time can expose the user to unprecedented security threats and challenges. Much of this threat comes from the fact that the devices connected in an IoT network share some level of trust and exchange information without performing any malware tests. The threats can broadly be classified into three categories. The categories are capture, disrupt and manipulate. The capture threat means capturing information or system without authorization. The capture threats are such threats that are designed to gain access to information that is either logical or physical on a network. The disrupt threat means denying access or destroying a system. The manipulate threat means manipulating time series data or identity. Multiple security vulnerabilities exist in the current system with the potential to result in security concerns including Insecure network services and software/firmware, lack of transport encryption, insecure cloud and mobile interface, insufficient security configurability and poor physical security, insufficient authorization/authentication, insecure web services and privacy concerns [32][33].

Table 3. The description of threats at each layer

\begin{tabular}{|c|c|}
\hline IoT Layers & Threats \\
\hline Application layer & $\begin{array}{l}\text { Malicious code attacks, Tampering with node-based applications, Inability } \\
\text { to receive security patches, Hacking into the smart meter/grid, Phishing } \\
\text { Attack, Malicious Virus/worm, Malicious Scripts, Remote configuration, } \\
\text { Misconfiguration, Security management, Management system }\end{array}$ \\
\hline Network layer & $\begin{array}{l}\text { DoS attack, Gateway Attacks, Unauthorized Access, Storage Attacks, } \\
\text { Injecting fake information, Spoofing Attacks, Sinkhole Attacks, Wormhole } \\
\text { Attacks, Man in the Middle Attack, Routing Attacks, Sybil Attacks, } \\
\text { Unauthorized Access }\end{array}$ \\
\hline Perception Layer & $\begin{array}{l}\text { RFID, Wireless Sensor Networks (WSN), Eavesdropping, Sniffing Attacks, } \\
\text { Noise in data, Privacy threats Services abuse, Identity masquerade ,Service } \\
\text { information Manipulation, Repudiation, Replay attack }\end{array}$ \\
\hline
\end{tabular}


International Journal of Network Security \& Its Applications (IJNSA) Vol. 11, No.2, March 2019

\section{Countermeasures (Existing And Proposed)}

The countermeasures that can be taken are the authentication measures, the establishment of trust and acceptance of federated architecture awareness of security issues.

Table 4. The countermeasure of threats at each layer

\begin{tabular}{|c|c|c|c|c|}
\hline IOT Layers & Protocols & Threats & Countermeasures & $\begin{array}{l}\text { Countermeasures } \\
\text { description }\end{array}$ \\
\hline \multirow[t]{8}{*}{$\begin{array}{l}\text { Application } \\
\text { layer }\end{array}$} & \multirow[t]{8}{*}{$\begin{array}{l}\text { CoAP, } \\
\text { DDS, } \\
\text { MQTT, } \\
\text { SMQTT, } \\
\text { AMQP }\end{array}$} & $\begin{array}{l}\text { Malicious code } \\
\text { attacks }\end{array}$ & $\begin{array}{lr}\text { Runtime } & \text { Type } \\
\text { Checking, } & \text { Firewall } \\
\text { Checks } & \end{array}$ & $\begin{array}{l}\text { Appear to do } \\
\text { runtime type } \\
\text { checking, making } \\
\text { them immune to } \\
\text { all ill-typed code } \\
\text { we tried. Firewall } \\
\text { checks have to be } \\
\text { done at runtime }\end{array}$ \\
\hline & & $\begin{array}{l}\text { Tampering with } \\
\text { node-based } \\
\text { applications }\end{array}$ & $\begin{array}{l}\text { Physically secure } \\
\text { design }\end{array}$ & $\begin{array}{l}\text { Physically Secure } \\
\text { Designing r of } \\
\text { devices should } \\
\text { not } \quad \text { be } \\
\text { changeable and } \\
\text { not be of high } \\
\text { quality[26] }\end{array}$ \\
\hline & & $\begin{array}{l}\text { Inability to receive } \\
\text { security patches }\end{array}$ & \multicolumn{2}{|c|}{$\begin{array}{l}\text { Avoiding security risks with regular } \\
\text { patching and support services }\end{array}$} \\
\hline & & $\begin{array}{l}\text { Hacking into the } \\
\text { smart meter/grid }\end{array}$ & \multicolumn{2}{|c|}{$\begin{array}{l}\text { Security Frameworks to Prevent Hacking } \\
\text { The Grid }\end{array}$} \\
\hline & & $\begin{array}{l}\text { Malicious } \\
\text { injection }\end{array}$ & $\begin{array}{l}\text { Use FileZilla as the } \\
\text { FTP client. }\end{array}$ & $\begin{array}{l}\text { You must know } \\
\text { that FileZilla } \\
\text { store the } \\
\text { credentials of } \\
\text { your websites in } \\
\text { plain text }\end{array}$ \\
\hline & & $\begin{array}{l}\text { Remote } \\
\text { configuration }\end{array}$ & $\begin{array}{l}\text { Configuring and } \\
\text { managing. VPNs }\end{array}$ & $\begin{array}{l}\text { NCP engineering } \\
\text { provides } \\
\text { software } \mathrm{VPN} \\
\text { platform the } \\
\text { solution that is } \\
\text { designed for an } \\
\text { organization that } \\
\text { requires control } \\
\text { over large } \\
\text { networks. }\end{array}$ \\
\hline & & $\begin{array}{l}\text { Application } \\
\text { security }\end{array}$ & $\begin{array}{l}\text { Web Application } \\
\text { Scanner }\end{array}$ & $\begin{array}{l}\text { Discovery of } \\
\text { various threats } \\
\text { which is present } \\
\text { on the front end } \\
\text { of web [24] }\end{array}$ \\
\hline & & $\begin{array}{l}\text { Security } \\
\text { management }\end{array}$ & \multicolumn{2}{|c|}{$\begin{array}{l}\text { Security management is the } \\
\text { identification of an organization's assets } \\
\text { followed by the development, } \\
\text { documentation, and implementation of } \\
\text { policies and procedures for protecting } \\
\text { these assets. }\end{array}$} \\
\hline
\end{tabular}


International Journal of Network Security \& Its Applications (IJNSA) Vol. 11, No.2, March 2019

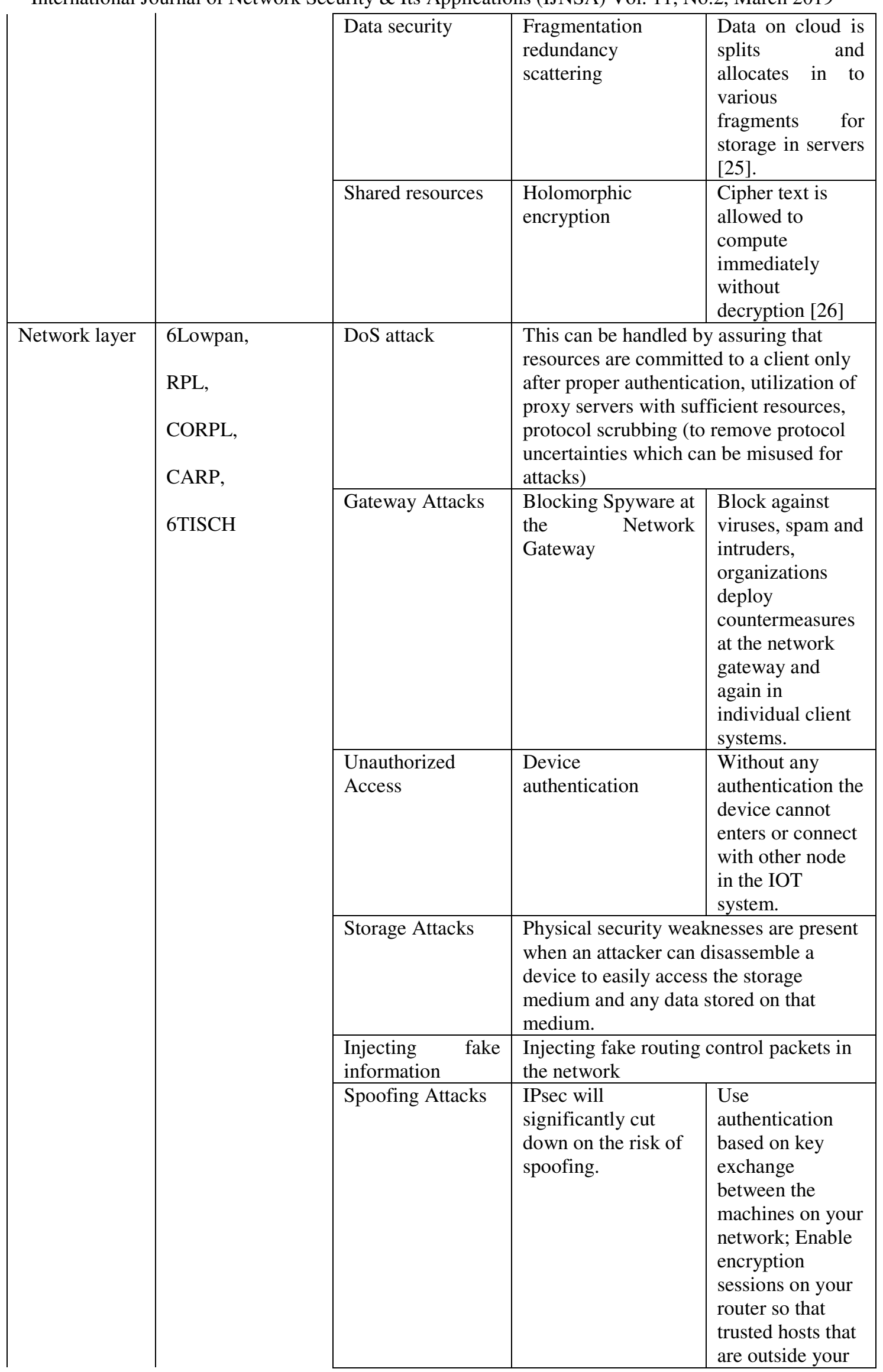


International Journal of Network Security \& Its Applications (IJNSA) Vol. 11, No.2, March 2019

\begin{tabular}{|c|c|c|}
\hline & & $\begin{array}{l}\text { network can } \\
\text { securely } \\
\text { communicate } \\
\text { with your local } \\
\text { hosts. }\end{array}$ \\
\hline Sinkhole Attacks & $\begin{array}{l}\text { Security aware and } \\
\text { ad-hoc routing }\end{array}$ & $\begin{array}{l}\text { Stops inside } \\
\text { attacks from the } \\
\text { network of IOT } \\
\text { and the adversary } \\
\text { is dropped from } \\
\text { the network. }\end{array}$ \\
\hline Wormhole Attacks & Routing Protocol & $\begin{array}{l}\text { Routing protocol } \\
\text { is used to } \\
\text { produce the } \\
\text { multiple paths } \\
\text { between the } \\
\text { sender and } \\
\text { receiver and } \\
\text { checks the } \\
\text { presence of route. } \\
\text { Physical } \\
\text { monitoring of } \\
\text { Field devices and } \\
\text { regular } \\
\text { monitoring of } \\
\text { network using } \\
\text { Source Routing. } \\
\text { Monitoring } \\
\text { system may use } \\
\text { packet leach } \\
\text { techniques. }\end{array}$ \\
\hline $\begin{array}{l}\text { Man in the Middle } \\
\text { Attack }\end{array}$ & $\begin{array}{l}\text { Secure/Multipurpose } \\
\text { Internet Mail } \\
\text { Extensions, or } \\
\text { S/MIME; } \\
\text { Authentication } \\
\text { Certificates }\end{array}$ & $\begin{array}{l}\text { Hackers will } \\
\text { never go away, } \\
\text { but one thing you } \\
\text { can do is make it } \\
\text { virtually } \\
\text { impossible to } \\
\text { penetrate your } \\
\text { systems by } \\
\text { implementing } \\
\text { Certificate Based } \\
\text { Authentication } \\
\text { for all employee } \\
\text { machines and } \\
\text { devices. }\end{array}$ \\
\hline $\begin{array}{l}\text { Routing } \\
\text { Information } \\
\text { Attacks }\end{array}$ & $\begin{array}{l}\text { Encrypting Routing } \\
\text { Tables }\end{array}$ & $\begin{array}{l}\text { was identifies } \\
\text { different security } \\
\text { issues on web by } \\
\text { encryption } \\
\text { process in rout }\end{array}$ \\
\hline Sybil Attacks & \multicolumn{2}{|c|}{$\begin{array}{l}\text { Trusted Certification, Resource Testing, } \\
\text { Recurring Fees, Privilege Attenuation, } \\
\text { Economic Incentives, Location/Position } \\
\text { Verification, Received Signal } \\
\text { Strength Indicator (RSSI)-based scheme } \\
\text { and Random Key Pre distribution. [28] }\end{array}$} \\
\hline
\end{tabular}


International Journal of Network Security \& Its Applications (IJNSA) Vol. 11, No.2, March 2019

\begin{tabular}{|c|c|c|c|c|}
\hline & & $\begin{array}{l}\text { Unauthorized } \\
\text { Access }\end{array}$ & & \\
\hline \multirow[t]{11}{*}{$\begin{array}{l}\text { Perception } \\
\text { smart, Layer }\end{array}$} & \multirow[t]{9}{*}{$\begin{array}{l}\text { LTE-A, } \\
\text { Z-Wave, } \\
\text { Zigbee DASH7, } \\
\text { 802.11ah }\end{array}$} & $\begin{array}{c}\text { RF interface on } \\
\text { RFID }\end{array}$ & $\begin{array}{l}\text { Device } \\
\text { authentication }\end{array}$ & $\begin{array}{l}\text { A new Physical } \\
\text { device before } \\
\text { sending and } \\
\text { receiving of data } \\
\text { the device should } \\
\text { authenticate itself }\end{array}$ \\
\hline & & $\begin{array}{c}\text { Jamming node in } \\
\text { Wireless Sensor } \\
\text { Networks (WSN) }\end{array}$ & $\begin{array}{l}\text { IPsec Security } \\
\text { channel }\end{array}$ & $\begin{array}{l}\text { Node tempering } \\
\text { and } \\
\text { eavesdropping } \\
\text { can be stopped } \\
\text { by changeable } \\
\text { and not be of } \\
\text { high quality [28] }\end{array}$ \\
\hline & & Eavesdropping & \multicolumn{2}{|c|}{$\begin{array}{l}\text { Session Keys protect NPDU from } \\
\text { Eavesdropper }\end{array}$} \\
\hline & & Sniffing Attacks & \multicolumn{2}{|c|}{$\begin{array}{l}\text { sniffer detection tools like ARP Watch, } \\
\text { Promiscan, Anti-Sniff, Prodetect }\end{array}$} \\
\hline & & Noise in data & & \\
\hline & & Privacy threats & RFID & \\
\hline & & Services abuse & & \\
\hline & & $\begin{array}{c}\text { Identity } \\
\text { masquerade }\end{array}$ & $\begin{array}{l}\text { verify identity; } \\
\text { strong password }\end{array}$ & $\begin{array}{l}\text { Generally, a } \\
\text { unique user ID is } \\
\text { assigned to each } \\
\text { user, but } \\
\text { passwords are } \\
\text { something you } \\
\text { must set (or } \\
\text { change) by } \\
\text { yourself. If your } \\
\text { User ID and } \\
\text { Password are } \\
\text { compromised or } \\
\text { stolen, somebody } \\
\text { else might use } \\
\text { them to access } \\
\text { your system or } \\
\text { other systems, } \\
\text { masquerading as } \\
\text { a legitimate user. }\end{array}$ \\
\hline & & $\begin{array}{c}\text { Service } \\
\text { information } \\
\text { Manipulation }\end{array}$ & & \\
\hline & & Repudiation & \multicolumn{2}{|c|}{$\begin{array}{l}\text { Create secure audit trails; Use digital } \\
\text { signatures }\end{array}$} \\
\hline & & Replay attack & \multicolumn{2}{|c|}{$\begin{array}{l}\text { Timestamps, one-time passwords, and } \\
\text { challenge response cryptography [28] }\end{array}$} \\
\hline
\end{tabular}

\section{Conclusions}

The field of IoT is still considered to be in its nascent stage and the technologies employed have considerable scope to progress. Security and privacy pose a very serious challenge to the researches and hinders the growth of IoT. Due to the fact that IoT is an emerging technology, attackers take advantage of the underlying potential to threaten theuser's privacy, security using 
International Journal of Network Security \& Its Applications (IJNSA) Vol. 11, No.2, March 2019

wide variety of attacks. This paper presents the comprehensive overview of security threats and attacks on IoT. Countermeasures of the security threats and attacks deliberated with the detail description. The future work involves finding alternative solutions for attacks that are less complex and less time consuming. The future research involves development of protocols and find ways to overcome security threats and attacks.

\section{FUTURE WORK}

The IoT is developing at a very rapid pace, and successful growth of IoT is only possible ifwe address the security and privacy challenges related to the internet of things. A secure IoT paradigm is possible only with the redressal of issues like $5 \mathrm{~g}$ protocols, key and identity management, fault tolerance, trust \&amp; group management and end-to-end security. As highlighted in this paper, work needs to done in the areas of IoT architecture, finding alternative solutions for attacks that are less complex in terms of time and other resources. Moreover, policies need to be devised concerning regulations, trust management, legal framework, and device security at the manufacturer's end.

\section{REFERENCES}

[1] J. Gubbi, R. Buyya, S. Marusic, M. Palaniswami, Internet of things (IoT): a vision, architectural elements, and future directions, Future Gener. Comput. Syst. 29 (7) (2013) 1645-1660.

[2] Roman, R., Najera, P., Lopez, J., 2011. Securing the internet of things. Computer 44 (9), 51_58.

[3] Horrow, S., and Anjali, S. (2012). Identity Management Framework for Cloud-Based Internet of Things. SecurIT ' 12 Proceedings of the First International Conference on Security of Internet of Things, 200-203. 2012

[4] Whitmore, A., Agarwal, A., and Da Xu, L. (2014). The Internet of Things: A survey of topics and trends. Information Systems Frontiers, 17(2), 261- 274.

[5] Aazam, M., St-Hilaire, M., Lung, C.-H., and Lambadaris, I. (2016). PRE-Fog: IoT trace based probabilistic resource estimation at Fog. 2016 13th IEEE Annual Consumer Communications and Networking Conference (CCNC), 12- 17.

[6] Jiang, H., Shen, F., Chen, S., Li, K. C., and Jeong, Y. S. (2015). A secure and scalable storage system for aggregate data in IoT. Future Generation Computer Systems, 49, 133- 141.

[7] Li, S., Tryfonas, T., and Li, H. (2016). The Internet of Things: a security point of view. Internet Research, 26(2), 337-359.

[8] A. Al-Fuqaha, M. Guizani, M. Mohammadi, M. Aledhari, and M. Ayyash. Internet of things: A survey on enabling technologies, protocols, and applications. IEEE Communications Surveys Tutorials, 17(4):2347-2376, Fourth quarter 2015.

[9] Pongle, P., and Chavan, G. (2015). A survey: Attacks on RPL and 6LoWPAN in IoT. 2015 International Conference on Pervasive Computing: Advance Communication Technology and Application for Society, ICPC 2015, 0(c), 0-5.

[10] Tsai, C.-W., Lai, C.-F., and Vasilakos, A. V. (2014). Future Internet of Things: open issues and challenges. Wireless Networks, 20(8), 2201-2217.

[11] V. Karagiannis, P. Chatzimisios, F. Vazquez-Gallego, and J. Alonso-Zarate, "A survey on application layer protocols for the internet of things," Transaction on IoT and Cloud Computing, vol. 3, no. 1, pp. $11-17,2015$ 
International Journal of Network Security \& Its Applications (IJNSA) Vol. 11, No.2, March 2019

[12] D. Locke, "MQ telemetry transport (MQTT) v3. 1 protocol specification," IBM Developer Works Technical Library, 2010, http://www.ibm.com/developerworks/webservices/library/wsmqtt/index.html

[13] M. Singh, M. Rajan, V. Shivraj, and P. Balamuralidhar, "Secure MQTT for the Internet of Things (IoT)," in Fifth International Conference on Communication Systems and Network Technologies (CSNT 2015), April 2015, pp. 746-751.

[14] OASIS, "OASIS Advanced Message Queuing Protocol (AMQP) Version 1.0," 2012, http://docs.oasis-open.org/amqp/core/v1.0/os/amqp-core-complete-v1.0-os.pdf

[15] T. Winter, et al., "RPL: IPv6 Routing Protocol for Low-Power and Lossy Networks," IETF RFC 6550, Mar. 2012, http://www.ietf.org/rfc/rfc6550.txt

[16] A. Aijaz and A. Aghvami, "Cognitive machine-to-machine communications for internet-of-things: A protocol stack perspective," IEEE Internet of Things Journal, vol. 2, no. 2, pp. 103-112, April 2015,

[17] http://ieeexplore.ieee.org/xpl/articleDetails.jsp?tp=\&arnumber=7006643

[18] Z. Zhou, B. Yao, R. Xing, L. Shu, and S. Bu, "E-CARP: An energy-efficient routing protocol for UWSNs on the internet of underwater things," IEEE Sensors Journal, vol. PP, no. 99, 2015, http://ieeexplore.ieee.org/xpl/articleDetails.jsp?arnumber=7113774

[19] D. Dujovne, T. Watteyne, X. Vilajosana, and P. Thubert, "6TiSCH: Deterministic IP-enabled industrial internet (of things)," IEEE Communications Magazine, vol. 52, no.12, pp. 36-41, December 2014, http://ieeexplore.ieee.org/xpl/articleDetails.jsp?arnumber=6979984

[20] M. Hasan, E. Hossain, D. Niyato, "Random access for machine-to-machine communication in LTEadvanced networks: issues and approaches," in IEEE Communications Magazine, vol. 51, no. 6, pp.86-93, June 2013 http://ieeexplore.ieee.org/xpl/articleDetails.jsp?reload=true\&arnumber=6525600

[21] Z-Wave, "Z-Wave Protocol Overview," v. 4, https://wiki.ase.tut.fi/courseWiki/imges/9/94/SDS10243_2_Z_Wave_Protocol_Overview.pdf

[22] ZigBee Standards Organization, "ZigBee Specification," Document 053474r17, Jan 2008, 604 pp., http://home.deib.polimi.it/cesana/teaching/IoT/papers/ZigBee/ZigBeeSpec.pdf

[23] O. Cetinkaya and O. Akan, "A dash7-based power metering system," in 12th Annual IEEE Consumer Communications and Networking Conference (CCNC), Jan 2015, pp. 406-411, http://ieeexplore.ieee.org/xpl/articleDetails.jsp?reload=true\&arnumber $=7158010$

[24] Zhang, Zhi-Kai, et al. "IoT security: ongoing challenges and research opportunities." ServiceOriented Computing and Applications (SOCA), 2014 IEEE 7th International Conference on. IEEE, 2014.

[28] D. Migault, D. Palomares, E. Herbert, W. You, G. Ganne, G. Arfaoui, and M. Laurent, "E2E: An Optimized IPsec Architecture for Secure And Fast Offload," in Seventh International Conference on Availability, Reliability and Security E2E: 2012.

[26] Abomhara, Mohamed, and Geir M. Køien. "Security and privacy in the Internet of Things: Current status and open issues." Privacy and Security in Mobile Systems (PRISMS), 2014 International Conference on. IEEE, 2014.

[27] B. L. Suto, "Analyzing the Accuracy and Time Costs of Web Application Security Scanners," San Fr., no. October 2007, 2010. 
International Journal of Network Security \& Its Applications (IJNSA) Vol. 11, No.2, March 2019

[28] O. El Mouaatamid, M. LahmerInternet of Things security: layered classification of attacks and possible countermeasures Electron J (9) (2016).

[29] Seda F. Gürses/Bettina Berendt/Thomas Santen, Multilateral Security Requirements Analysis for Preserving Privacy in Ubiquitous Environments, in Bettina Berendt/Ernestina Menasalvas (eds), Workshop on Ubiquitous Knowledge Discovery for Users (UKDU '06), at 51-64;

[30] Stankovic, J. (2014). Research directions for the internet of things.IEEE Internet of Things Journal, $1(1), 3-9$

[31] Sicari, Sabrina, et al. "Security, privacy and trust in the Internet of Things: The road ahead." Computer Networks76 (2015): 146-164.

[32] https://www.cso.com.au/article/575407/internet-things-iot-threats-countermeasures/ Accessed on 1503-2019

[33] Bokhari, Mohammad Ubaidullah, and Faheem Masoodi. "Comparative analysis of structures and attacks on various stream ciphers." Proceedings of the 4th National Conference. 2010. 